\title{
TRADISI BULAN MUHARAM DI INDONESIA
}

\author{
Japarudin \\ Fakultas Ushuluddin, Adab dan Dakwah IAIN Bengkulu \\ Jalan Raden Fatah Pagar Dewa Bengkulu \\ j4p4rudin@gmail.com
}

\begin{abstract}
Muharam Month Tradition In Indonesia. The rich cultural traditions of Indonesian society are colored by Islam as a religion of the majority. The touch of Islam with the local culture leads to a diversity of Islamic nuanced traditions. The tradition in the month of Muharam in Indonesian society which is generally performed on 1-10 Muharam, is represented in various forms and varieties. In Aceh there is the tradition of Asan Usin moon, West Sumatra with Tabuik tradition, Bengkulu has Ark tradition. While in the land of Java, the most menunjol is the tradition of carnival in the palace of Jogjakarta and Solo. This paper describes the diversity of the community's traditions in historical and cultural perspectives.
\end{abstract}

Keywords: Kanji Acura, Suro, Tabuik, Tabut.

Abstrak: Tradisi Bulan Muharam di Indonesia. Kekayaan tradisi budaya masyarakat Indonesia diwarnai oleh Islam sebagai agama yang dianut oleh masyarakat mayoritas. Persentuhan Islam dengan budaya lokal membawa pada keberagaman tradisi yang bernuansa Islam. Tradisi di bulan Muharam pada masyarakat Indonesia yang secara umum dilakukan pada tanggal 1-10 Muharam, direpresentasikan dalam berbagai bentuk dan ragam. Di Aceh terdapat tradisi bulan Asan Usin, Sumatra Barat dengan tradisi Tabuik, Bengkulu memiliki tradisi Tabut. Sedangkan di tanah Jawa, yang paling menunjol adalah tradisi kirab di kraton Jogjakarta dan Solo. Tulisan ini mendeskripsikan keberagaman tradisi masyarakat tersebut dalam perspektif sejarah dan budaya.

Kata Kunci: Kanji Acura, Suro, Tabuik, Tabut.

\section{Pendahuluan}

Bulan Muharam merupakan bulan

pertama dalam sistem kalender Qamariyah (kalender Islam), sehingga 1 Muharam merupakan awal tahun baru Hijriyah. Bulan Muharam dikenal juga dengan sebutan bulan Syuro/Asyuro. Berbagai tradisi dilakukan oleh masyarakat Islam pada bulan Muharam di Indonesia. Sehingga banyak terdapat aktifitas tertentu pada yang dilakukan oleh sebagian besar masyarakat Indonesia.

Keberagaman budaya, agama, dan keyakinan masyarakat Indonesia telah mewarnai berbagai tradisi dan ritual yang dilakukan masyarakat pada bulan Muharam. Berbagai tradisi itu antara lain, membuat makanan berupa bubur merahputih, mencuci keris, membaca doa-doa, menyantuni anak yatim, dan sampai pada peristiwa budaya seperti tradisi kirab di Solo dan Yogyakarta, bulan Asan Usen di Aceh, tradisi Tabut di Bengkulu dan Tabuik di Pariaman Sumatera Barat.

Jika dicermati ekspresi masyarakat di bulan Muharam atau dikenal juga dengan Asyura tepatnya tanggal 10 Muharam dapat dikelompokkan dalam kelompok. Kelompok pertama berasumsi bahwa 10 Muharram dianggap hari yang dapat mendatangkan berkah dan keberuntungan yang berlipat sehingga diperingati dengan belanja aneka barang kebutuhan ataupun dengan mengadakan berbagai perayaan sukacita. Beberapa perayaan lain yang dilakukan misalnya dengan pesta bubur jepe suro (bubur Muharam) yang dilakukan di masyarakat Takalar, propinsi Sulawesi Selatan. 
Perayaan bubur ini diyakini dapat mendatangkan rezeki yang berlimpah. ${ }^{1}$

$$
\text { Sedangkan kelompok kedua }
$$

berasumsi bahwa Muharam sebagai bulan berduka dan kesedihan diekspresikan dalam bentuk pelaksanaan tradisi menolak bencana, pada bulan Muharam kelompok ini cenderung berduka dan berdoa meminta perlindungan dari Allah SWT. Beberapa tradisi yang ada misalnya tradisi Tabut di Bengkulu, tradisi bubur tujuh macam di beberapa daerah, tradisi Jawa berupa penyucian benda-benda keramat, atau tradisi Barzanji, maupun bubur Suro di Sunda.

\section{Pembahasan}

\section{A. Tradisi Asyuro di Jawa}

Di Sumenep Madura, tradisi Muharaman diwarnai dengan tradisi membuat bubur. Bulan Muharam dalam bahasa Madura disebut dengan bulan Sora. Ketika bulan Sora, orang-orang Madura membuat bubur tajin dan menyebutnya Tajin Sora terbuat dari bubur nasi dengan kuah ketan. Kemudian memasuki bulan Shafar orang Madura membuat Tajin Mera Pote (Bubur Merah Putih) karena bubur itu terdiri dari dua warna. Warna putih dari santan dan warna merah dari gula, dan di dalamnya ada bola bola yang terbuat dari tepung ketan. Biasanya antar tetangga saling bersedekah bubur selama Muharam. Dalam pandangan tradisional orang Madura, bulan Muharam dianggap sebagai bulan nahas, sehingga dilarang melakukan perjalanan jauh pada bulan tersebut. Warna merah pada Tajin Suro dimaknai, sebagai gambaran darah Sayyidina Husein, putih itu menggambarkan kesucian perjuangan Sayyidina Husein. ${ }^{2}$

Tradisi bubur suro merupakan salah satu cara yang dilakukan masyarakat Jawa Barat (khususnya Tasikmalaya dan Limbangan, Garut) untuk menyambut datangnya bulan Muharam sekaligus mengenang wafatnya cucu Nabi Muhammad SAW di medan peperangan. Pagi hari setiap tanggal sepuluh Muharam, hampir setiap rumah penduduk memasak bubur merah dan bubur putih secara terpisah dan dikenal dengan sebutan bubur suro. Selanjutnya, bubur suro akan dibawa ke masjid bersama dengan beragam makanan ringan lainnya. Penduduk yang mengikuti acara di masjid akan duduk membentuk lingkaran dan acara tersebut akan dipimpin oleh orang yang dituakan di daerah tersebut. Seorang wanita paruh baya akan membacakan solawat dan pujian bagi Rasullulah SAW yang diambil dari kitab al-Barzanzi. Seusai al-Barzanzi dilantunkan, maka akan diceritakanlah kisah hidup Husein bin Ali bin Abi Thalib, perjuangannya dalam menegakkan keadilan hingga Huein bin Ali yang syahid di medan peperangan. Setelah pembacaan kisah usai, maka para penduduk akan bersama-sama menikmati hidangan yang telah disajikan. ${ }^{3}$

Berbagai aktifitas seperti yang dikemukakan di atas, titik temunya adalah adanya kebiasaan di masyarakat melakukan lelaku maupun tradisi dan ritual khusus di bulan Muharam. Hal yang kedua pada titik kesamaan tradisi ini adalah makan dan hidangan yang dibuat, umumnya mempunyai kemiripan, dikenal dengan bubur merah putih, ataupun bubur Asyura yang bahan pembuatannya 
juga tidak jauh berbeda, yakni dengan memanfaatkan hasil bumi Indonesia.

Titik tolak aktifitas tahun Suro (Asyura) di dalam masyarakat Jawa, dimulai sejak upaya revolusioner yang dilakukan oleh Sultan Agung dalam memadukan sistem kalender Saka (penanggalan yang merupakan perpaduan dari Jawa asli dan Hindu) dengan sistem kalender Islam Hijriyah. Sultan Agung raja kerajaan Mataram (1613-1645), melakukan perubahan sistem kalender ini terjadi dan dimulai pada tanggal 1 Sura tahun Alip 1555, tepat pada tanggal 1 Muharam tahun 1043 Hijriyah, atau tepat pada tanggal 8 Juli 1633 Masehi. ${ }^{4}$

Satu Suro merupakan hari pertama dalam kalender Jawa di bulan Sura atau Suro. Pergantian tahun baru Jawa ini memang jatuh tiap malam 1 Suro atau 1 Muharam. Dahulu masyarakat Jawa masih mengikuti sistem penanggalan Tahun Saka yang diwarisi dari tradisi Hindu. Sedangkan, umat Islam pada masa Sultan Agung, Raja Mataram menggunakan sistem kalender Hijriah. Kemudian sebagai upaya memperluas ajaran Islam di tanah Jawa, Sultan Agung memadukan antara tradisi Jawa dan Islam dengan menetapkan 1 Muharram sebagai tahun baru Jawa. ${ }^{5}$

Berbagai aktifitas dilakukan masyarakat Jawa dalam menyambut malam tahun tahun baru Suro yang bertepatan dengan malam 1 Muharam, namun jika dibandingkan dengan penyambutan tahun baru Masehi (malam 1 Januari) maupun tahun baru Cina (Imlek), yang umumnya disambut dengan euforia dan berbagai kemeriahan, akan tetapi tahun baru Suro disambut dengan renungan instrospeksi diri dan berbagai ritual,satu aktifitas euforia yang berbeda.

Kota Solo, Kraton Surakarta dan Yogyakarta, Kraton Yogyakarta sebagai bagian dari pusat budaya Jawa, menjadi ikon utama dan sering disoroti saat tibanya tanggal 1 Suro, karena berbagai aktifitas di dua wilayah tersebut sering menjadi pusat perhatian publik. Di Kraton Ngayogyakarta Hadiningratmemperingati Malam 1 Suro dengan cara mengarak benda pusaka mengelilingi benteng kraton yang diikuti oleh ribuan warga Yogyakarta dan sekitarnya. Selama melakukan ritual mubeng beteng tidak diperkenankan untuk berbicara seperti halnya orang sedang bertapa. Inilah yang dikenal dengan istilah tapa mbisu mubeng beteng. Sedangkan di Kraton Surakarta Hadiningrat kirab malam 1 Suro dipimpin oleh Kebo Bule Kyai Slamet sebagai Cucuking Lampah. Kebo Bule merupakan hewan kesayangan Susuhunan yang dianggap keramat. Di belakang Kebo Bule barisan berikutnya adalah para putra Sentana Dalem (kerabat keraton) yang membawa pusaka, kemudian diikuti masyarakat Solo dan sekitarnya seperti Karanganyar, Boyolali, Sragen dan Wonogiri. ${ }^{6}$

Pergantian tahun baru Jawa umumnya diperingati pada malam hari, setelah magrib pada hari sebelum tanggal tersebut dan disebut sebagai malam 1 Suro. Peringatan pergantian tahun Jawa memang dimulai pada saat matahari terbenam dari hari sebelumnya, bukan pada tengah malam. Saat malam 1 Suro tiba, masyarakat Jawa umumnya melakukan berbagai ritual, di antaranya tirakatan atau kegiatan intropeksi diri, lek-lekan atau tidak tidur 
semalam suntuk, Kungkum atau berendam di sungai besar, atau sumber mata air tertentu, ngumbah Keris, tradisi membersihkan keris pusaka bagi orang yang memilikinya dan tuguran (perenungan diri sambil berdoa). ${ }^{7}$

Di Cirebon, Suroan mengacu pada hari pertama maupun hari kesepuluh bulan Sura atau Muharam. Masyarakat Cirebon melakukan slametan atau sedekah yang diyakini merupakan suatu bentuk ibadah dengan cara membuat bubur sura atau bubur slabrak (bubur tepung beras dengan santan yang berisi berbagai bahan makanan) untuk dibagikan kepada tetangga atau kerabat dekat. Pesan dibalik tradisi ini tampak dari bubur warna putih yang menandakan hari Asyura yang suci, sedangkan berbagai macam bahan makanan yang ada dalam bubur menjadi simbol berbagai kejadian pada hari yang sedang diperingati. Slametan dengan memberikan bubur Suro masih umum dilakukan oleh masyarakat, terdapat anggapan bahwa memberikan bubur sura kepada kerabat dan tetangga merupakan cara cepat mengungkapkan kewajiban berzikir mengingat Allah. ${ }^{8}$

Terdapat anggapan di masyarakat pesisir Jawa, bahwa bubur Syuro ada hubungannya - menggambarkan peristiwa banjir masa Nabi Nuh. Ketika banjir sudah berhenti dan Nabi Nuh turun dari Kapal, maka tidak ada makanan apapun kecuali tepung, dan tepung tersebut dibuat bubur. Jadilah makanan bubur tersebut dianggap sebagai penghormatan dari peristiwa yang dialami oleh Nabi Nuh. ${ }^{9}$

Tradisi malam 1 Suro menitikberatkan pada ketentraman batin dan keselamatan. Karenanya, pada malam
1 Suro biasanya selalu diselingi dengan ritual pembacaan doa dari semua umat yang hadir merayakannya. Hal ini bertujuan untuk mendapatkan berkah dan menangkal datangnya marabahaya. ${ }^{10}$ Ritual Ngumbah (mencuci) keris, kirab kerbau bule dan benda pusaka di kraton Surakarta, tradisi Mubeng Beteng di kraton Yogyakarta, ritual tirakatan, ritual tapa bisu, tradisi nonton wayang kulit semalam suntuk. ${ }^{11}$

Di desa Mlangi Nogotirto Sleman Yogyakarta, peringatan Asyura dilakukan dengan memasak Sega Megana yang dibawa ke masjid untuk dibagikan kepada anak-anak, terutama anak yatim, sementara orang-orang dewasa pada hari itu melakukan puasa sunnah. Tidak jauh berbeda dengan di Kota Gede, tepatnya di dusun Darakan, pada tanggal 10 Muharam msayarakat (terutama generasi tua) membuat jenang panggul. Pembuatan jenang panggul dimaksudkan untuk menolak bahaya. Demikian pula dengan masyarakat desa Prenggan Kota Gede, sampai tahun 2002 masih berlaku tradisi pembuatan jenang sura. ${ }^{12}$

Sedikit berbeda dengan di Mojokuto - selama Clifford Geertz berdomisili di daerah ini - disebutkan bahwa masyarakat Mojokuto, Meskipun ada tradisi slametan tanggal 10 di bulan sura atau Muharam akan tetapi masyarakat tidak pernah melakukan tradisi membuat bubur, Geertz menulis:

Untuk menghormati Hasan dan Husen, keduanya cucu Nabi, yang menurut cerita ingin mengadakan slametan untuk Nabi Muhammad ketika beliau sedang berperang melawan kaum kafir. Mereka membawa beras (dimana mereka memperoleh beras di negeri Arab tidak 
dipersoalkan) ke sungai untuk dicuci, tetapi kuda musuh mengahampiri dan menendang beras itu ke sungai. Kedua anak itu menangis dan memungut beras yang telah bercampur dengan pasir dan kerikil. Namun mereka memasaknya juga menjadi bubur. Dengan demikian slametan ini ditandai oleh dua mangkuk bubur- yang satu dengan kerikil dan pasir di dalamnya untuk dimakan para cucu, dan satunya lagi dengan kacang potongan ubi goreng untukmelambangkan ketidakmurnian, yang akan dimakan oleh orang dewasa. Walaupun beberapa orang mengatakan bahwa upacara keagamaan yang pada dasarnya berasal dari kaum Syiah dan sudah berubah menurut daerah ini, kadang-kadang masih diadakan, tapi tidak pernah saya lihat ada yang melakukannya di Mojokuto, dan pada umumnya memang jarang terdapat. ${ }^{13}$

\section{B. Tradisi pada bulan Muharam di Aceh}

Membaca buku Seputar Masuknya Islam Ke Indonesia karya Aboebakar Atjeh, penulis mendapatkan pernyataan bahwa di Kampung Kedah ditempat kelahiran Aboebakar Atjeh, orang sering melaksanakan perayaan tabut Hasan Husein yang setiap tahun diadakan di Kutaraja. Adalah Tuanku Raja Keumala, keluarga India yang memainkan peranan penting dalam upacara Tabut Hasan Husein di Kampung Kedah, sebagai penghormatan atas kejadian yang sedih di Karbala, masyarakat memasak bubur yang bercampur buah-buahan dan dibagikan kepada orang yang melewati jalan. Perayaan Tabut Hasan Husein baru saja terhapus di beberapa daerah di Sumatera pada waktu akhir-akhir ini (penulis. era saat buku ini ditulis, yakni tahun 1980-an). ${ }^{14}$

Di Aceh, untuk memperingati bulan Asyura masyarakat membuat Kanji Asyura yang terbat dari beras, susu, kelapa, gula, buah-buhan, kacang tanah, pepaya, delima, pisang dan akar-akaran. Setiap bulan Muharam masyarakat Aceh memasak Kanji Asyura di suatu tempat, kemudian dibawa ke masjid atau ke perempatan jalan, dan setelah dibacakan doa, kemudian dibagikan kepada masyarakat. ${ }^{15}$

Informasi lain menyebutkan bahwa masyarakat Aceh melaksanakan ritual Asan Usen di bulan Muharam. Masyarakat memasak dan menyuguhkan makanan khas yang digunakan untuk memperingati bulan Asan Usen ini, yakni apa yang disebut dengan Kanji Acura, bahan makanan ini terdiri dari beras, santan kelapa, gula, kacang-kacangan (reute), pepaya (boh peute), delima (boh glima), dan umbi-umbian. Kanji Acura ini akan diletakkan disuatu tempat yang telah ditentukan yang disiapkan secara komunal di Meunasah. Pada hari pertama memasuki bulan Asan Usen, masyarakat melaksanakan puasa selama tiga hari berturut-turut, kemudian puasa akan dilanjutkan pada sore hari di hari kesembilan dengan berbuka puasa memakan kanji acura. ${ }^{16}$

\section{Tradisi Tabuik di Sumatera Barat}

Tabut dikenal juga di Sumatera Barat, tepatnya di Pariaman, dan disebut dengan sebutan logat setempat yakni Tabuik. Menurut informasi yang diperoleh, Tabuik di Pariaman berasal dari Bengkulu yang dibawa oleh bangsa Cipei atau keling yang dipimpin oleh Imam 
Kadar Ali. Bangsa Cipei ini merupakan sisa pasukan Inggris di Bengkulu. Tabuik di Pariaman dikembangkan oleh Mak Sakarana dan Mak Sakaujana, dan merupakan orang yang mempelopori Tabuik pasar dan Tabuik Kampung Jawa. Tabuik pasar melahirkan Tabuik Cimparuh, Bato dan Karan Aur. Sedangkan Tabuik Kampung Jawa melahirkan Tabuik Pauh, Jati, Sungai Rotan. ${ }^{17}$ Jika pelaksanaan tradisi Tabut di Bengkulu memiliki tahapan-tahapan tertentu (di antaranya diawali dengan ngambik tanah) dan berakhir dengan Tabut tebuang, maka Tabuik di Pariaman juga memiliki tahapan pelaksanaan tradisi, dikutip dari Ernatip $\mathrm{dkk}^{18}$ berikut ini tahapan pelaksanaan Tabuik di Pariaman:

a. Barantam. Kegiatan ini dipimpin oleh wali nagari yang dikenal dengan istilah janang. Jika yang bersangkutan tidak ada atau atau berhalangan, maka digantikan oleh orang lain yang dituakan dalam nagari.

b. Pembuatan Tabuik dilakukan secara bersama-sama yang dipimpin oleh seorang tukang Tabuik. Tukang Tabuik adalah orang yang sudah ahli dalam pembuatan Tabuik. Pekerja Tabuik dibagi dalam tiga kelompok, dan ada satu orang sebagai ketua sekaligus perancang kerangka Tabuik.

c. Mengambil tanah dipimpin oleh orang siak (pemimpin upacara) dan pawang Tabuik. Pawang Tabuik adalah pemimpin dari semua kegiatan yang berhubungan langsung dengan kegiatan inti. Sedangkan orang siak hanya memimpin pembacaan doa sebelum berangkat dan setelah kembali mengambil tanah. Dalam hal ini pawang Tabuik adalah orang yang menyelam ke dasar sungai untuk mengambil tanah. Sebelum terjun ke sungai pawang Tabuik membakar kemenyan disertai dengan mantramantra sesuai dengan apa yang diterimanya dari pendahulunya. Mantra yang dibacakan tersebut ditujukan untuk dirinya, benda yang akan diambilnya, dan tempat pengambilannya.

d. Mengambil batang pisang juga dipimpin oleh orang siak (pemimpin upacara) dan pawang Tabuik. Orang siak bertugas memimpin pembacaan doa sebelum berangkat dan setelah kembali mengambil batang pisang. Sedangkan pawang Tabuik bertugas menebang batang pisang. Sebelum melakukan pekerjaanya pawang Tabuik juga membaca mantra-mantra.

e. Maarak penja/jari-jari dipimpin oleh orang siak (pemimpin upacara) untuk membacakan doa sebelum berangkat dan setelah kembali maarak penja/jari. Pawang Tabuik bertugas mengambil duplikat jari-jari dari rumah Tabuik untuk dibawa ke daraga, baru berkeliling kampung. Setelah itu pawang Tabuik mengembalikan penja ke rumah Tabuik.

f. Maarak sorban dipimpin oleh orang siak (pemimpin upacara) untuk membaca doa sebelum berangkat dan setelah kembali dari maarak sorban. Pawang Tabuik bertugas mengambil dan mngembalikan sorban dari dan kerumah Tabuik. Sorban itu dibawa berkeliling kampung.

g. Tabuik naik pangkat dipimpin oleh orang siak (pemimpin upacara) dan pawang Tabuik. Orang siak memimpin pembacaan doa ketika Tabuik hendak 
dibawa ke pasara. Sedangkan pawang Tabuik membacakan mantra dan memberi pemanis pada Tabuik yang akan dibawa ke pasar.

h. Ma-oyak tabuik dipimpin oleh orang siak (pemimpin upacara) dan pawang Tabuik. Orang siak memimpin pembacaan doa ketika hendak memulai ma-oyak Tabuik. Sedangkan pawang Tabuik membaca mantramantra agar Tabuik dan pesertanya tidak mendapat musibah, terhindar dari perbuatan jahat dari Tabuik lawan atau manusia lainnya.

i. Membuang Tabuik dipimpin oleh pawang Tabuik.

Menurut Hamka, asumsi yang menyatakan bahwa Tabuik (Tabut) di Padang adalah pengaruh Syi'ah, dan asumsi ini sangat lemah. Beberapa sarjana Barat berpendapat bahwa sebelum Mazhab Syafi'i tersebar di Minangkabau 'ada kemungkinan' terlebih dahulu ada Mazhab Syi'ah. Atau ada pengaruh Syi'ah di Minangkabau, terbukti adanya perayaan Tabut Hasan-Husin di beberapa kota, seperti di Padang, Pariaman, dan Padang Panjang. Hipotesis demikian sebagai suatu kemungkinan dapat diterima dan tidak ada yang menghalangi buat ditolak. Karena apa yang telah ditaksir oleh Sarjana Barat, belumlah mutlak benar. Jika hanya dengan adanya perayaan Tabot, bukan berarti orang Minangkabau penganut Mazhab Syi'ah. Mungkin pula perayaan Tabut itu didorong oleh rasa sangat cinta kepada keturunan (cucu-cucu) Rasulullah. Dan yang herannya pula, tidak terdapat di zaman ini perayaan Tabut itu di negeri Syi'ah sendiri (Iran), atau di negeri yang banyak Syi'ahnya (Irak). ${ }^{19}$ Lebih lanjut Hamka mengemukakan:

Di Irak dan di Iran, negeri yang penduduknya bermazhab Syi'ah, perayaan Tabut itu tidak ada. Tabut itu tidak pernah dipelopori oleh ulama. Ulama yang ada di Padang Panjang (termasuk ayah saya) seketika saya berusia 10 tahun itu diam dalam seribu bahasa terhadap tabut. Orang Cipai membujuk orang kampung yang awam. Orang kampungpun mau membantu bergotong royong keluar uang pembeli kertas pembuat tabut, atau membeli bambu untuk badan tabut, sebab emosi mereka disingung. Dibangkitkan rasa cinta dan sedih atas kematian Sayyidina Husain di Padang Karbala, berperang dengan "Raja Kafir" bernama "Sulthan Bayazid". Lalu seorang pengarang syair cara lama, bernama Bagindo Malin mengarang sebuah buku syair bernama "Syair Hasan-Husain" dan dinyanyikan.

Mereka hanya mengikuti saja mazhab guru yang mempengaruhinya. Sebab itu kalau ada tabut terhoyak hosen, merekapun turut bertabut-tabut, sehingga lama kelamaan menjadi kebiasaan yang tidak tentu lagi asal usulnya. Sehingga di Padang, Pariaman dan seluruh Minangkabau kalau ada orang yang bergembira-gembira bersorak sorai disebut "Berhoyak Hosen" yang asalnya dari kalimat "O Ya Husain". Dan kalau ada orang berkelahi sekampungsekampung yang disebut juga "Cakak berbelah" yaitu berbelahan kampung. Misalnya di antara orang kampung Sebelah dengan orang Kampung Palinggam, orang Kampung Pauh dengan Kampung Jawi-jawi, disebut "Bertabuiktabuik".20 
Meskipun telah mengalami pergeseran perubahan tradisi, apa yang dikemukakan oleh Hamka di atas menunjukkan adanya nilai gotong royong, dan memberikan informasi bagaimana perkembangan tradisi Tabuik di Sumatera Barat. Selain perubahan makna, difusi dan akulturasi budaya tampak dari penggunaan "o ya Husein" maupun penggunaan kata serapan Bertabuik-tabuik, yang diserap dari kata tabuik untuk menunjukkan adanya perkelahian.

\section{Tradisi Tabut di Bengkulu}

Kajian tentang Tabut di Bengkulu sudah cukup banyak dilakukan, dalam bentuk penelitian maupun berbagai seminar ilmiah. Bagian ini penulis mencoba mengemukakan wacana yang diekstrak dari pembacaan penulis dari berbagai literatur dan karya ilmiah tentang Tabut, diketahui bahwa terdapat dua wacana tentang Tabut di Bengkulu, yakni pemikiran yang menyatakan bahwa Tabut merupakan tradisi budaya yang bernuansa Syi'ah, dan pemikiran yang menyatakan Tabut lebih dominan bernuansa budaya lokal.

Kelompok pemikiran pertama berasumsi dengan bersandar pada argumen bahwa pada pelaksanaan tradisi Tabut tertuju pada peringatan wafatnya Husein bin Ali tanggal 10 Muharam. Sedangkan kelompok pemikiran yang kedua bersandar pada simbol dan pengakuan para pelaku tradisi, sehingga berkesimpulan Tabut juga bernuansa budaya lokal. Identifikasi penulis terhadap dua wacana tenang tradisi Tabut tersebut, membawa pada beberapa hal yang menurut penulis kontradiktif dalam pemaknaan tradisi Tabut yang menarik untuk dikaji yakni:

Pertama, tradisi Tabut yang dilaksanakan setiap bulan Muharam di kota Bengkulu, oleh beberapa kalangan diasumsikan sebagai tradisi yang memberikan penghormatan, memuliakan, dan memperingati peristiwa Padang Karbala, yakni pertempuran cucu Nabi Muhammad SAW yang bernama Husein bin Ali dengan tentara Yazid. Namun sisi lain yang menarik untuk diteliti adalah, Keluarga Pelaksana Tradisi (KPT) Tabut mengaku kalau KPT Tabut tidak termasuk Islam Syi'ah, akan tetapi KPT Tabut adalah masyarakat Melayu Bengkulu. Dalam kehidupan beragama, keluarga Tabut menjalankan ibadah seperti orang beragama Islam pada umumnya, tidak terdapat doktrin seperti yang dilakukan oleh kaum Syi'ah yang mengkultuskan keturunan Ali bin Abi Thalib. ${ }^{21}$ Mengenai hal ini, menarik apa yang dikemukakan oleh Hamka tentang Tabut di Minangkabau:

Jika hanya dengan adanya perayaan Tabot, bukan berarti orang Minangkabau penganut Mazhab Syi'ah. Mungkin pula perayaan Tabot itu didorong oleh rasa sangat cinta kepada keturunan (cucucucu) Rasulullah. Menunjukkan cinta kepada keturunan Rasulullah belumlah sekaligus dapat diartikan bahwa orang jadi pengikut Syi' ah. ${ }^{22}$

Diperlukan kajian lebih lanjut jika tradisi Tabut dikatakan tradisi Syi'ah hanya karena adanya simbol Husein bin Ali, karena bagaimanapun Syi'ah mempunyai karakteristik tersendiri sebagai salah satu aliran dalam Islam. Sedangkan Tabut mengandung perpaduan simbol Islam, budaya lokal, 
dan kepercayaan masyarakat Bengkulu pra-Islam. Dan hal penting lainnya adalah kalangan Sunni (ahlussunnah wal jamaah), merupakan kaum yang mencintai ahlul bait, keluarga Rasulullah Muhammad SAW.

\begin{tabular}{llr}
\multicolumn{2}{c}{ Kedua, jika } & ada asumsi bahwa \\
tradisi Tabut & dilakukan untuk \\
menghormati & leluhur, yang
\end{tabular}
direpresentasikan melalui berbagai simbol yang menjadi perlengkapan dalam prosesi tradisi Tabut. Dalam hal ini masih dipertanyakan leluhur siapa yang dihormati, apakah leluhur tersebut ditujukan kepada Husein bin Ali atau leluhur orang Bengkulu, yakni leluhur para KPT tabut yang tergabung dalam Kerukunan Keluarga Tabut (KKT). Hal ini satu aspek yang penting untuk diketahui, guna 'meluruskan' ataupun melengkapi kajian tentang tradisi Tabut di Bengkulu.

$$
\text { Ketiga, adanya anggapan }
$$

masyarakat bahwa tradisi Tabut dilaksanakan agar masyarakat kota Bengkulu terhindar dari segala macam kesusahan dan menolak Balak (bencana), seperti pada tahun 1988 masyarakat diserang wabah penyakit cacar air, dan ini diyakini oleh masyarakat disebabkan tidak dilaksanakannya tradisi Tabut pada tahun tersebut. ${ }^{23}$ Tradisi Tabut pada masa pendudukan Jepang (1942-1945) pernah tidak dilaksanakan. ${ }^{24}$ Terdapat anggapan bahwa gempa bumi tahun 2000 yang melanda Bengkulu, dianggap sebagai akibat dari tidak dilaksanakannya tradisi Tabut. Selain itu adanya masyarakat rebutan mengambil air cucian Penja, yang diyakini suci dan mampu menyembuhkan semua penyakit merupakan satu fenomena tersendiri. Menarik apa yang ditulis oleh Hakim Benardie:
Kesenian Tabot pada awal abad ke18 dibawa oleh tentara Inggris yang umumnya berasal dari etnik Shimphahi di kaki gunung Himalaya India. Pembawa kesenian Tabot itu bukanlah orang-orang penganut agama Hindhu atau Buddha yang baik, dan muslimpun tidak. Mereka adalah tentara sewaan dan budak tentara Inggris (Gurca) yang dibawa ke Indonesia. Gurca ini banyak mengenal berbagai kebudayaan di India dan Persia. Kesenian inilah yang dikembangkannya di Bengkulu dan Pariaman Sumatera Barat.

Secara jujur kita dapat melihat dari berbagai proses pensakralan dalam prosesi pembuatan Tabot serta ritual pembuangannya di Bengkulu, yang diklaim sebagai salah satu kesenian budaya daerah. Dari prosesi ritual Tabot akan terlihat jelas bagaimana kentalnya budaya Hindhu dan Bhuddha melekat, dan dibungkus dalam kemasan Islam. Silahkan cermati secara sunguhsunguh, bagaimana prosesi ritual Tabot di Kampung Berkas dan Kampung Kepiri. Di sana terdapat bangunan Stupa (Tangkup sebagaimana yang terdapat di Candi Borobudur), dan pada hari perayaannya stupa tersebut diberi kelambu secara khusus. Benda sakral seperti ini juga terdapat di salah satu di sudut Benteng Marlborough menghadap kepelabuhan laut lama, juga terdapat sebuah Gerga Batu di Kampung Berkas. ${ }^{25}$

Keempat, dilihat dari simbol-simbol sebagai pesan komunikasi yang ada dalam tradisi Tabut, masing-masing simbol mempunyai makna pesan yang ingin disampaikan. Menurut Irwan Abdullah, simbol dengan maknanya menjadi suatu objek yang dihasilkan melalui proses negosiasi yang melibatkan 
berbagai pihak dengan kepentingannya masing-masing. ${ }^{26}$ Artinya, simbol yang ada dalam tradisi Tabut sangat mungkin memuat berbagai kepentingan dari berbagai pihak. Tidak hanya kepentingan akan memperingati peristiwa Padang Karbala.

Simbol lainnya sebagai indikator tinggalan kepercayaan pra Islam dalam tradisi Tabut adalah digunakannya simbol Tebu Hitam. ${ }^{27}$ Menurut Peneng dan Sumantera, tebu digunakan oleh umat Hindu Bali sebagai bahan sesajen dalam suatu upacara. Tebu dapat bermakna simbolis memberikan rasa kehidupan, identitas diri dan penolak balak. Tebu digunakan sebagai alat untuk menghaluskan/Nguyeng Sekah (simbol orang yang diaben) berupa tebu hitam. Ini bermakna pembersihan/penyucian dan persembahan agar leluhur yang diupacarai (diaben) menjadi bersih/suci, sehingga diharapkan dapat diterima di sisi-Nya, sedang yang masih hidup diberi kekuatan lahir dan batin. ${ }^{28}$

Kelima, patut diragukan, jika tradisi Tabut dibawa oleh suku Sipai yang didatangkan sebagai tenaga untuk membangun benteng Marborough di Bengkulu oleh Inggris, dan suku Sipai ini berasal dari India, sedangkan India merupakan negara dengan penduduk beragama Hindu. Artinya meskipun orang Sipai beragama Islam, tidak menutup kemungkinan ideologi Hindu (penggunaan tebu hitam, bangunan Tabut yang berundak seperti bangunan Pura, Gerga, dan lain sebagainya yang turut mewarnai ke-Islaman orang Sipai. Sehingga tradisi Tabut merupakan tradisi yang lahir dengan akulturasi IslamHindu.
Keenam, komunitas Syi'ah menjadikan hari kematian Husein bin Ali di Karbala tanggal 10 Muharam (hari Asyura) sebagai hari berkabung. Menurut Lapidus, rasa berkabung atas kematian Husein menjadi upacara ritual yang sangat penting sebagai identifikasi diri atas derita syuhada, ${ }^{29}$ dan tidak ditemukan penjelasan bagaimana bentuk ritual dimaksud dalam karya Lapidus. Namun terdapat informasi tentang tradisi berduka masyarakat Syiraz-Iran pada bulan Muharam. Dikemukakan bahwa pada hari Asyura masyarakat membawa tabut-tabut para syuhada yang telah dulumuri dengan darah, mereka meletakkan beberapa pedang dan 'amamah (sorban di kepala) milik para syuhada dengan hiasan sayap-sayap burung di atas tabut-tabut tersebut. Setelah acara selesai, setiap kelompok menguburkan tabut-tabut tersebut dengan prosesi sebuah acara. ${ }^{30}$

Meskipun satu kesatuan dalam bentuk sebuah pelaksanaan satu tradisi bernama Tabut, terdapat dua kutub pendapat yang berbeda, Tabut dengan nuansa Islam Syi'ah dan Tabut dengan budaya lokal, dan keduanya (Islam Syi'ah maupun budaya lokal), mempunyai ideologinya $^{31}$ masing-masing. Dalam kawasan idea suatu budaya, istilah ideologi meliputi; nilai, norma, falsafah, kepercayaan religius dan sebagainya. ${ }^{32}$ Ideologi juga merupakan sistem kepercayaan dan sistem nilai. ${ }^{33}$

Upacara Tabut merupakan rangkaian peringatan atas wafatnya Husein bin Ali bin Abi Thalib. Namun karena telah berkesinambungannya upacara Tabot, ditambah dengan masuknya berbagai unsur yang meliputi 
sosial budaya dan pola kehidupan masyarakat Bengkulu dari masa ke masa, dan sejalan dengan perkembangan zaman, memungkinkan terjadi pergeseran tema Tabot pada periode akhir-akhir ini. ${ }^{34}$

Perlu dipertimbangkan kembali jika klaim yang diberikan didasarkan atas keberadaan sebuah simbolis, pergeseran makna simbolis dapat saja terjadi. Sebagai contoh, menurut Bastomi yang dikutip oleh Sofwan mengemukakan bahwa dahulunya makanan dalam masyarakat Jawa dapat memiliki makna simbolis dan diperlakukan sebagai sesaji, maka sekarang dimaknai sebagai makanan biasa. Demikian juga dengan upacara slametan yang dahulunya dilakukan dengan tujuan ngalap berkah, ditujukan kepada roh tertentu, namun sekarang hampir semua hal dapat dislameti. ${ }^{35}$ Sehingga dapat ditegaskan bahwa simboli dapat mengalami perubahan makna seiring dengan peredaran masa dan perubahan zaman.

Diperlukan kajian lanjutan sebelum berkesimpulan bahwa tradisi Tabut adalah tradisi yang bernuansa Islam Syi'ah. Karena tidak menutup kemungkinan, momen 10 Muharam dicaplok sebagai waktu yang tepat untuk melaksanakan tradisi Tabut. Karena tidak dapat diabaikan begitu saja keyakinan masyarakat yang tergabung dalam KKT, yakni komunitas yang meyakini tradisi Tabut merupakan ritual menolak bencana (balak). Merupakan kesimpulan yang terlalu dini apabila tradisi Tabut dikatakan sebagai bagian Islam Syi'ah jika hanya dilihat peringatan kematian Husein bin Ali, karena selain hal tersebut dalam tradisi Tabut terdapat simbol dan bendabenda sakral lainnya, yang lebih dominan dan merupakan produk lokal sebagai warisan kepercayaan masyarakat praIslam yang tentu mempunyai makna tersendiri. Dengan kata lain, mungkinkah tradisi Tabut di Bengkulu merupakan produk kebudayaan lokal, atau memang merupakan pengaruh dari faham Syi'ah, diperlukan kajian lebih lanjut.

\section{Simpulan}

Kepercayaan dan sejarah dapat mempengaruhi budaya lokal, demikian pula dengan Islam. Islam masuk dalam budaya dengan mewarnai atau bahkan mengganti budaya yang tidak sesuai dan bertentangan dengan Islam. kenyataan ini membawa pada munculnya budaya dengan spirit Islam, seperti tradisi budaya di bulan Muharam. Asimilasi ataupun integrasi Islam dan budaya lokal menjadikan kekayaan budaya bernuansa Islam di Indonesia.

\section{Referensi}

1"Salah Kaprah 10 Muharam" dalam http://www.kompasiana.com/andiwahyudin ./salah-kaprah-10-

muharram_5519a49fa33311701ab6591c, dikases tanggal 6/8/2015

${ }^{2}$ Mengenai hal ini dapat dibaca artikel "Tradisi Asyuro di Indonesia" dalam http://indonesian.irib.ir/editorial/cakrawala /item/87417-tradisi-asyuro-di-indonesia, diakses pada tanggal 6 Agustus 2015.

3"Tradisi Menyambut Datangnya Bulan Muharam di Indonesia" dalam http:/ / www.lebaran.com/tahun-baru-islam1435-h/item/1551-tradisi-menyambutdatangnya-bulan-muharram-diindonesia.html, dikases 6/8/2015.

${ }^{4}$ Hersapandi, "Sejarah Perkembangan Tahun Baru Jawa dan Perilaku Sosial-Budaya Orang Jawa: Suatu Pengantar" dalam Suran Antara Kuasa Tradisi dan Ekspresi Seni, (Yogyakarta: Pustaka Marwah, 2005), 4. 


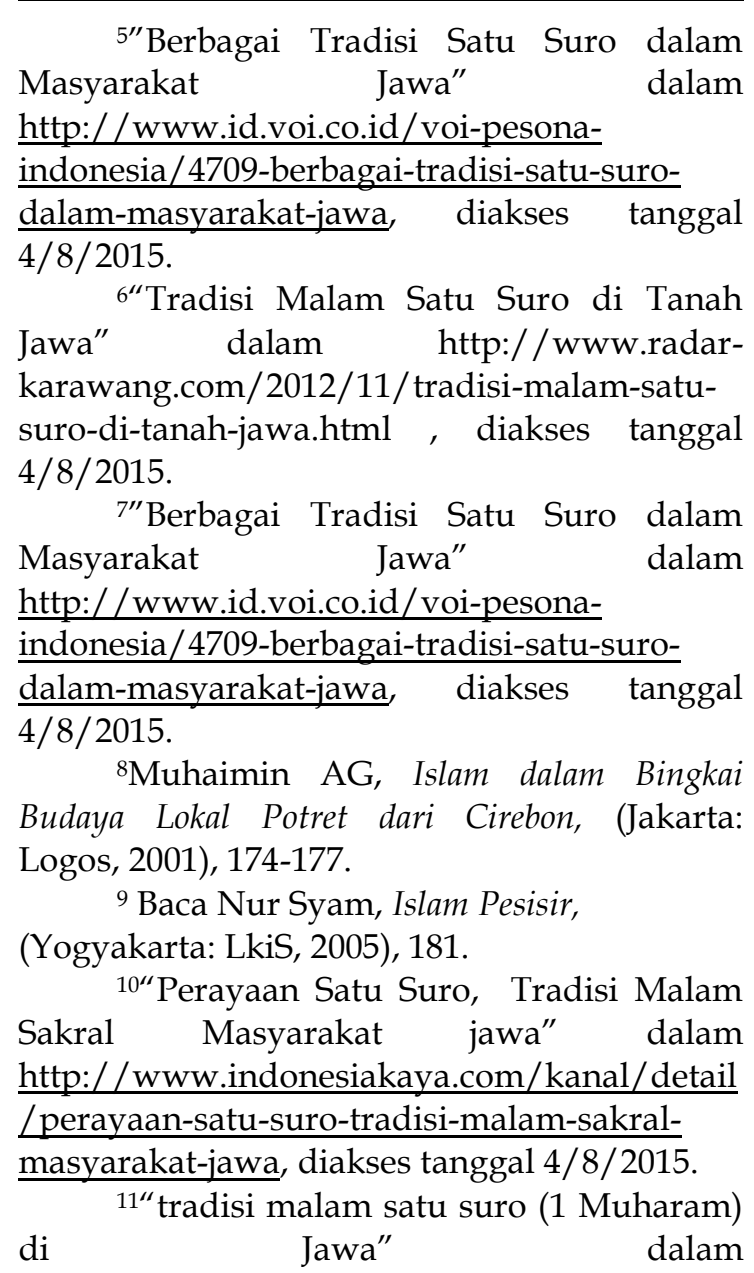

http://www.wartainfo.com/2015/03/tradisiritual-malam-satu-suro-1.html, dikases tanggal 6/8/2015

12Siti Maryam. Tradisi Syi'ah Dalam Komunitas Ahlusunah Waljama'ah Indonesia, (Disertasi pada Pascasarjana UIN Sunan Kalijaga Yogyakarta, tahun 2009), 207.

${ }^{13}$ Clifford Geertz, Abangan, Santri, Priyayi dalam Masyarakat Jawa, (Jakarta: Pustaka Jaya, 1983), 105.

${ }^{14}$ Aboebakar Atjeh, Sekitar Masuknya Islam ke Indonesia, (Solo: Ramadhani, 1985), 3334.

15Siti Maryam, Tradisi Syi'ah Dalam Komunitas Ahlusunah Waljama'ah Indonesia, (Disertasi pada Pascasarjana UIN Sunan Kalijaga Yogyakarta, tahun 2009), 286.

16Rini Fitria. Ritual Tabut sebagaiMedia Komunikasi Masyarakat Kota Bengkulu (Pola Komunikasi Pelaksanaan Ritual Tabut di Kota Bengkulu), (Tesis pada Pascasarjana Universitas Padjajaran Bandung, tahun 2005), 122.
17Zainul Anwar, Tabut dan Peranannya dalam Masyarakat, (Padang: Proyek Permuseuman Sumbar, 1982), 14.

${ }^{18}$ Ernatip, dkk. Upacara Tabuik di Pariaman: Kajian Nilai Budaya dan Fungsi bagi Masyarakat Pendukungnya, (Departemen Kebudayaan dan Pariwisata Dirjen Nilai Budaya, Seni dan Film, 2001), 24.

${ }^{19}$ Hamka, Antara Fakta dan Khayal Tuanku Rao, (Jakarta: Bulan Bintang, 1974), 78-81.

${ }^{20}$ Hamka, Antara Fakta dan Khayal Tuanku Rao, 117-120.

21 Rini Fitria, Ritual Tabut Sebagai Media Komunikasi Masyarakat Kotamadia Bengkulu, (Bandung: Tesis pada Pasca Sarjana Universitas Padjajaran, tidak diterbitkan, 2005), 158.

22 Hamka, Antara Fakta dan Khayal Tuanku Rao, (Jakarta: Bulan Bintang, 1974), 7881.

${ }^{23}$ Rini Fitria, Ritual Tabut Sebagai Media Komunikas, 157.

24 Depdikbud RI, Sejarah Daerah Bengkulu, 186.

25 Hakim Benardie, "Bengkulu dalam Lintasan Sejarah Phamnalayu" dalam Sarwit Sarwono, dkk (editor). Bunga Rampai Melayu Bengkulu, (Bengkulu: Dinas Pariwisata Propinsi Bengkulu, 2004), 354-355.

26 Irwan Abdullah, Rekonstruksi dan Reproduksi Kebudayaan, (Yogyakarta: Pustaka Pelajar, 2006), 5.

27 Meskipun demikian, asumsi ini diperlukan kajian lebih lanjut dan mendalam. Mengingat hampir sebagian besar tanah di negeri nusantara (Indonesia) dapat ditemukan tanaman jenis tebu hitam ini. di daerah asal penulis (Kabupaten Kaur), tebu hitam digunakan sebagai bahan pembuat Ragi dan ada juga digunakan sebagai bahan obatobatan.

${ }^{28}$ Lihat I Nyoman Peneng dan I Wayan Sumantera, "Pemanfaatan Tebu dalam Upacara adat di kabupaten Tabanan, Bali" dalam Biodiversitas, Vol. 6. No. 2. (UPT Balai Konservasi Tumbuhan Kebun Raya 'Eka Karya' Bali, Tahun 2005), 138-139.

29 Ira M. Lapidus, Sejarah Sosial Umat Islam, (Jakarta: Rajawali Pers, 2000), 249.

${ }_{30}$ Muhammad Zafar Iqbal, Kafilah

Budaya, (Jakarta: Citra, 2006), 136.

31Ideologi yang dimaksud dalam penelitian ini adalah cara berpikir seseorang 
atau kelompok, paham (aliran, haluan, pandangan) dan tujuan yang mengarah pada nuansa Islam Syi'ah, maupun nuansa budaya lokal yang direpresentasekan melalui berbagai tanda dan simbol dalam tradisi Tabut.

${ }^{32}$ David Kaplan, Teori Kebudayaan terj. Landung Simatupang, (Yogyakarta: Pustaka Pelajar, 2002), 154.

${ }^{33}$ Yasraf Amir Piliang, Hipersemiotika Tafsir Cultural Studies Atas Matinya Makna, (Yogyakarta: Jalasutra, t.t), 18.

34 Budhisantoso dkk, Sinopsis Upacara Tradisional Daerah Bengkulu (Upacara Tabot di Kotamadya Bengkulu), (Jakarta: Departemen Pendidikan dan Kebudayaan Direktorat Jenderal Kebudayaan, Direktorat Sejarah Nilainilai Tradisional, Proyek Inventarisasi dan Dokumentasi Kebudayaan Daerah Bengkulu, 1986), 34.

${ }^{35}$ Ridin Sofwan, "Para Wali

Mengislamkan Tanah Jawa" dalam Ridin Sofwan dkk, Merumuskan Kembali Interelasi Islam-Jawa, (Yogyakarta: Gama Media, 2004), 13.

Abdullah, Irwan. Rekonstruksi dan Reproduksi Kebudayaan, Yogyakarta: Pustaka Pelajar, 2006.

Anwar, Zainul. Tabut dan Peranannya dalam Masyarakat, Padang: Proyek Permuseuman Sumbar, 1982.

Atjeh, Aboebakar. Sekitar Masuknya Islam ke Indonesia, Solo: Ramadhani, 1985.

Benardie, Hakim. "Bengkulu dalam Lintasan Sejarah Phamnalayu" dalam Sarwit Sarwono, dkk (editor). Bunga Rampai Melayu Bengkulu, Bengkulu: Dinas Pariwisata Propinsi Bengkulu, 2004.

Budhisantoso dkk, Sinopsis Upacara Tradisional Daerah Bengkulu (Upacara Tabot di Kotamadya Bengkulu), Jakarta: Departemen Pendidikan dan Kebudayaan Direktorat Jenderal Kebudayaan, Direktorat Sejarah Nilainilai Tradisional, Proyek Inventarisasi dan Dokumentasi Kebudayaan Daerah Bengkulu, 1986.

Depdikbud RI, Sejarah Daerah Bengkulu, Jakarta: Depdikbud RI, 1977/1978.

Ernatip, dkk. Upacara Tabuik di Pariaman: Kajian Nilai Budaya dan Fungsi bagi Masyarakat Pendukungnya, Departemen Kebudayaan dan Pariwisata Dirjen Nilai Budaya, Seni dan Film, 2001.

Fitria, Rini. Ritual Tabut Sebagai Media Komunikasi Masyarakat Kotamadia Bengkulu, Bandung: Tesis pada Pasca Sarjana Universitas Padjajaran, tidak diterbitkan, 2005.

Geertz, Clifford. Abangan, Santri, Priyayi dalam Masyarakat Jawa, Jakarta: Pustaka Jaya, 1983.

Hamka, Antara Fakta dan Khayal Tuanku Rao, Jakarta: Bulan Bintang, 1974.

Hersapandi, "Sejarah Perkembangan Tahun Baru Jawa dan Perilaku Sosial-Budaya Orang Jawa: Suatu Pengantar" dalam Suran Antara Kuasa Tradisi dan Ekspresi Seni, Yogyakarta: Pustaka Marwah, 2005.

Iqbal, Muhammad Zafar. Kafilah Budaya, Jakarta: Citra, 2006.

Kaplan, David. Teori Kebudayaan terj. Landung Simatupang, Yogyakarta: Pustaka Pelajar, 2002.

Lapidus, Ira M. Sejarah Sosial Umat Islam, Jakarta: Rajawali PePeneng, I Nyoman dan I Wayan Sumantera, "Pemanfaatan Tebu dalam Upacara adat di kabupaten Tabanan, Bali" dalam Biodiversitas, Vol. 6. No. 2. (UPT Balai Konservasi Tumbuhan Kebun Raya 'Eka Karya' Bali, Tahun 2005.

Muhaimin AG, Islam dalam Bingkai Budaya Lokal Potret dari Cirebon, Jakarta: Logos, 2001.

Maryam, Siti. Tradisi Syi'ah Dalam Komunitas Ahlusunah Waljama'ah Indonesia, Disertasi pada Pascasarjana UIN Sunan Kalijaga Yogyakarta, tahun 2009.

Piliang, Yasraf Amir. Hipersemiotika Tafsir Cultural Studies Atas Matinya Makna, Yogyakarta: Jalasutra, t.t.

Sofwan, Ridin. "Para Wali Mengislamkan Tanah Jawa" dalam Ridin Sofwan dkk, Merumuskan Kembali Interelasi Islam-Jawa, Yogyakarta: Gama Media, 2004.

Syam, Nur. Islam Pesisir, Yogyakarta: LkiS, 2005.

"Salah Kaprah 10 Muharam" dalam http://www.kompasiana.com/andiwa hyudin./salah-kaprah-10muharram_5519a49fa33311701ab6591c, dikases tanggal 6/8/2015 
“Tradisi Asyuro di Indonesia" dalam http://indonesian.irib.ir/editorial/cakr awala/item/87417-tradisi-asyuro-diindonesia, diakses pada tanggal 6 Agustus 2015.

“Tradisi Menyambut Datangnya Bulan Muharam di Indonesia" dalam http://www.lebaran.com/tahun-baruislam-1435-h/item/1551-tradisimenyambut-datangnya-bulanmuharram-di-indonesia.html, diakses 6/8/2015.

"Berbagai Tradisi Satu Suro dalam Masyarakat Jawa" dalam http://www.id.voi.co.id/voi-pesonaindonesia/4709-berbagai-tradisi-satusuro-dalam-masyarakat-jawa, diakses tanggal 4/8/2015.

"Tradisi Malam Satu Suro di Tanah Jawa" dalam http://www.radarkarawang.com/2012/11/tradisi-malamsatu-suro-di-tanah-jawa.html , diakses tanggal 4/8/2015.

"Berbagai Tradisi Satu Suro dalam Masyarakat Jawa" dalam http://www.id.voi.co.id/voi-pesonaindonesia/4709-berbagai-tradisi-satusuro-dalam-masyarakat-jawa, diakses tanggal 4/8/2015.

"Perayaan Satu Suro, Tradisi Malam Sakral Masyarakat jawa" dalam http://www.indonesiakaya.com/kanal $\angle$ detail/perayaan-satu-suro-tradisimalam-sakral-masyarakat-jawa, diakses tanggal 4/8/2015.

"Tradisi malam satu suro (1 Muharam) di Jawa" dalam http://www.wartainfo.com/2015/03/tr adisi-ritual-malam-satu-suro-1.html, dikases tanggal 6/8/2015 